Article

\title{
Feeling Blue by Extension: Intrafamily Transmission and Economic Pressures Explain the Native-Immigrant Gap in Well-Being among Youth in Switzerland
}

\author{
Oriane Sarrasin ${ }^{1, *}$, Eva G. T. Green ${ }^{1}$, Gina Potarca ${ }^{2}$, Claudio Bolzman ${ }^{3}$ and Ursina Kuhn ${ }^{4}$ \\ ${ }^{1}$ Institute of Psychology, University of Lausanne, CH-1015 Lausanne, Switzerland; E-Mails: oriane.sarrasin@unil.ch (O.S.), \\ eva.green@unil.ch (E.G.) \\ 2 Institute of Demography and Socioeconomics, University of Geneva, CH-1204 Geneva, Switzerland; \\ E-Mail: gina.potarca@unige.ch \\ ${ }^{3}$ Department of Social Work, University of Applied Sciences and Arts Western Switzerland, HES-SO, CH-1211 Geneva, \\ Switzerland; E-Mail: claudio.bolzman@hesge.ch \\ ${ }^{4}$ FORS - Swiss Centre of Expertise in the Social Sciences, CH-1015 Lausanne, Switzerland; E-Mail: ursina.kuhn@fors.unil.ch \\ * Corresponding author
}

Submitted: 5 July 2019 | Accepted: 19 November 2019 | Published: 27 December 2019

\begin{abstract}
Several factors explain the native-immigrant gap in well-being frequently found among adolescents and young adults. First, discrimination and integration challenges impact the psychological health of immigrants of all ages. Though rarely studied, low parental well-being is transmitted thereby also deteriorating youth well-being. Second, individuals with an immigrant background generally endure economic pressures to a greater extent than natives, which impact children through a lower parental well-being independently of origins. These factors-intrafamily transmission of negative affect and economic pressures-have been mostly studied separately (and only rarely for the former). Combining the two, the present study uses Swiss Household Panel data to examine the extent to which immigrant background and economic pressures relate to well-being of adolescents and young adults through the negative affect experienced by their mothers and fathers. In Switzerland, young people with an immigrant background-both immigrants and dual citizens-reported being more anxious, sad and depressed than natives. Path models showed that young people with foreign roots were more likely to live in a household that experienced economic pressures, which, in turn, related to impaired parental (mothers and fathers alike) well-being and finally their own. An immigrant background, economic pressures and parental well-being were also independently related to young people's negative affect, highlighting the complexity of the factors underlying the well-known immigrant-native gap in well-being.
\end{abstract}

\section{Keywords}

economic pressure; health; immigration; parental transmission; Swiss Household Panel; well-being

\section{Issue}

This article is part of the issue "Immigration from the Migrants' Perspective" edited by Alice Ramos (Institute of Social Sciences, Portugal), Eldad Davidov (University of Cologne, Germany/University of Zurich, Switzerland), Peter Schmidt (University of Giessen, Germany), Marta Vilar Rosales (Institute of Social Sciences, Portugal) and Dina Maskileyson (University of Cologne, Germany).

(C) 2019 by the authors; licensee Cogitatio (Lisbon, Portugal). This article is licensed under a Creative Commons Attribution 4.0 International License (CC BY). 


\section{Introduction}

\subsection{The Immigrant-Native Gap in Subjective Well-Being}

Compared to national citizens with no foreign roots (hereafter, natives), individuals with an immigrant background in Europe have been repeatedly found to report poorer subjective well-being; that this, they tend to express less positive (e.g., happiness, elation, contentment) and more negative (e.g., sadness, depression, anxiety) affects (Diener, Suh, Lucas, \& Smith, 1999). Indeed, recent cross-national studies showed that immigrants are less satisfied with life (Arpino \& de Valk, 2018; Heizmann \& Böhnke, 2019) and express more depressive symptoms than natives (Levecque \& van Rossem, 2015; Missinne \& Bracke, 2012; for supporting single-country evidence see, for instance, Bengi-Arslan, Verhulst, van der Ende, \& Erol, 1997; Levecque, Lodewyckx, \& Bracke, 2009). These studies further revealed that the gap in subjective well-being is wider when comparing natives and first-generation immigrants, compared to secondgeneration immigrants. Thus, individuals with a longer history or stronger ties with the receiving country appear to fare better in terms of well-being, which echoes a meta-analysis showing positive links between biculturalism, and psychological and socio-cultural adjustment (Nguyen \& Benet-Martínez, 2013). It is likely that more recent immigrants experience higher levels of discrimination and face greater integration challenges (e.g., Ford, 2011; Havekes, Uunk, \& Gijsberts, 2011), which are known to partly explain the immigrant-native gap in subjective well-being (e.g, Oppedal, Røysamb, \& Sam, 2004; Özbek, Bongers, Lobbestael, \& van Nieuwenhuizen, 2015; Schunck, Reiss, \& Razum, 2015). Lower social capital (e.g., less opportunities for meeting friends and participating in social activities on a regular basis) also explains why first-generation immigrants report lower subjective well-being than second-generation immigrants and natives (Arpino \& de Valk, 2018).

The immigrant-native gap in subjective well-being has been observed across all age categories, including early stages of life (for a review see Stevens \& Vollebergh, 2008). Thus, adolescents and young adults with an immigrant background suffer from a double disadvantage: Not only are they likely to suffer from discrimination and integration challenges themselves, but they may also have to navigate early transitions into adulthood-e.g., finding their first job, finding their (first) partner-with the support of parents who do not have the same resources and social capital as native parents. Generally, parents' psychological health impacts the well-being of offspring. A meta-analysis revealed that the presence of psychological issues in mothers (vs. in fathers) had a slightly greater impact on their children's negative affect (e.g., depressed mood, anxiety), especially among young children (Connell \& Goodman, 2002; see also Pilowsky et al., 2014). More specifically regarding minority families, previous studies looking at the US showed that be- longing to a racial minority group affects the well-being of children and adolescents, not only directly but also indirectly, through a lower parental well-being (Anderson et al., 2015; Hou, Kim, Hazen, \& Benner, 2017). Despite the established relationships between the mental health of parents and their offspring, few studies-and to our knowledge none in Europe-have examined the extent to which the emotional well-being of adolescents and young people with an immigrant background is related to that of their parents (e.g., among Latinos in the US, see Aisenberg, Trickett, Mennen, Saltzman, \& Zayas, 2007; for immigrants in Israel, see Walsh, Harel-Fisch, \& FogelGrinvald, 2010).

Uniting research on both the immigrant-native gap in subjective well-being and parental transmission of mental health issues, we expect that the lower subjective well-being (e.g., higher levels of negative affects such as anxiety and sadness) reported by adolescents and young adults in families with an immigrant background (compared to native families) is partly due to their parents' low well-being. Findings of previous studies suggest that the gap should be wider among individuals with a more recent immigration history or weaker ties with the receiving country. Yet immigrant background is intertwined with socioeconomic status. As described in the next section, economic hardships and pressure indeed impact children's well-being through the well-being of their parents, independently of individuals' national origin (e.g., Conger \& Conger, 2002).

\subsection{The Interplay between Immigrant Background and Socio-Economic Status}

The Family Stress Model (FSM; Conger \& Conger, 2002; Conger, Conger, \& Martin, 2010) has been developed to explain how economic hardship and pressures lead to child and adolescent maladjustment through parents' psychological distress and interparental relationship issues. According to the model, research should take into account both objective socio-economic indicators (e.g., being below the poverty line) and "day-to-day strains and hassles that unstable economic conditions create for families such as difficulty paying bills or being unable to purchase basic necessities" (Masarik \& Conger, 2017 , p. 86). Economic pressures have been found to relate to a greater distress among parents (e.g., LandersPotts et al., 2015; Ponnet, 2014). Lower parental subjective well-being then impairs the well-being of children (Zhang, 2014) and adolescents (White, Liu, Nair, \& Tein, 2015) through disruptions in parenting (e.g., an increase in harshness and/or a decrease in warmth). Economic pressures and parental distress have long term impacts: When experienced during childhood, they have long lasting effects on individuals' well-being throughout both adolescence (Sobolewski \& Amato, 2005) and adulthood (Kavanaugh, Neppl, \& Melby, 2018).

While the FSM was developed to account for the effect of economic pressures on children's and adolescents' 
well-being, its reasoning "also applies to various environmental stressors" (Masarik \& Conger, 2017, p. 85). Therefore, the present research investigates how having an immigrant background and enduring economic pressures jointly affect the well-being of adolescents and young adults. Indeed, low socio-economic status constitutes an additional explanation of the immigrantnative gap in subjective well-being, on top of discrimination and integration challenges. A large-scale study conducted in the Netherlands for instance showed that lower life satisfaction reported by respondents of Turkish and Moroccan origin (aged between 14 and 45) was almost fully explained by economic pressures and a low level of social capital (de Vroome \& Hooghe, 2014; for a similar study including several European countries see also de Vroome \& Hooghe, 2015. Thus, it is likely that, within families with an immigrant background, economic pressures generate negative affect among parents, which further relates to impaired well-being among their children. We test this indirect route from immigrant background to well-being. While immigration may result in having a lower socio-economic status than natives, the two factors may also interact. In a study conducted among Latino children in the US, the highest levels of internalizing disorders (e.g., anxiety, depression etc.) were indeed found among those whose parents reported immigration-related stress (e.g., discrimination) and economic pressures (Mendoza, Dmitrieva, Perreira, Hurwich-Reiss, \& Watamura, 2017). For this reason, the interaction between immigrant background and living in a household with a lower socio-economic status will be explored, too. The possible relationships between having an immigrant background, experiencing economic pressures and the subjective well-being of parents and their offspring are summarized in Figure 1.

\section{The Present Study}

The hypotheses developed in the present article were tested in Switzerland, a country with one of the highest proportion of immigrants in Europe. In 2018, 25.1\% of the resident population did not possess Swiss citizenship (Swiss Federal Statistical Office [SFSO], 2019b), which is partly explained by restrictive naturalization policies (Helbling, 2010). Most immigrants come from Western and Southern Europe (the most represented national groups are Italians, Germans, Portuguese and
French). According to a recent representative Swiss survey (SFSO, 2019a), $24 \%$ of the population declared having suffered from discrimination during the previous five years. The majority of the cases (58\%) was related to respondents' nationality. Some groups appear to be less tolerated, such as immigrants from Muslim countries, Africa and Former Yugoslavia (Rapp, 2015; Stolz, 2005). Overall, immigrants are more likely to be poor than Swiss citizens ( $8.5 \%$ vs. $7 \%$ ). The proportion rises to $9.4 \%$ for first-generation immigrants, while second-generation immigrants (4.6\%) fare better than national citizens (SFSO, 2019f). Finally, the employment rate of natives and individuals with an immigrant background varies across genders. First-generation immigrant men are more likely to be employed $(90.1 \%)$ than second-generation immigrants $(86.7 \%)$ and natives $(88.1 \%)$. By way of contrast, the employment share of native women (81.8\%) is higher than that of first $(74.7 \%)$ and second-generation (80.9\%) immigrant women. When immigrants work, they work longer hours (SFSO, 2019e; note that these statistics do not concern asylum seekers and refugees).

Immigrants' health has been found to be worse in Switzerland and other European assimilationist countries than in countries endorsing multicultural policies (Malmusi, 2015). Analyzing a set of Swiss laws and practices, from the wearing of Islamic veils by school teachers to TV programs, Giugni and Passy $(2004$, p. 62) indeed found that "the general policy is one of denial of the difference of ethnic groups in favour of allegiance to the norms and values of the host society." In addition, as in other European countries, first-generation immigrants in Switzerland report worse general health than national citizens (79.6\% declared being in good health vs. $84.9 \%$ of Swiss citizens). The best health was reported by immigrants" children, or the so-called "second generation" (88.5\%; SFSO, 2019c). Similarly, dual citizens (at birth or naturalized early in life) reported better health than immigrants or those who obtained the national citizenship later in life (Potarca \& Bernardi, 2018). The pattern is slightly different when looking at immigrants' subjective well-being. Among individuals aged 65 or more from Spain, Portugal and Italy, Bolzman and Vagni (2018) found that both immigrants and naturalized immigrants have a poorer psychological health than Swiss natives. Echoing these results, a greater proportion of foreign (44.5\%) and Swiss born (41.6\%) immigrants compared to Swiss citizens born in the country $(32.8 \%)$ report feeling

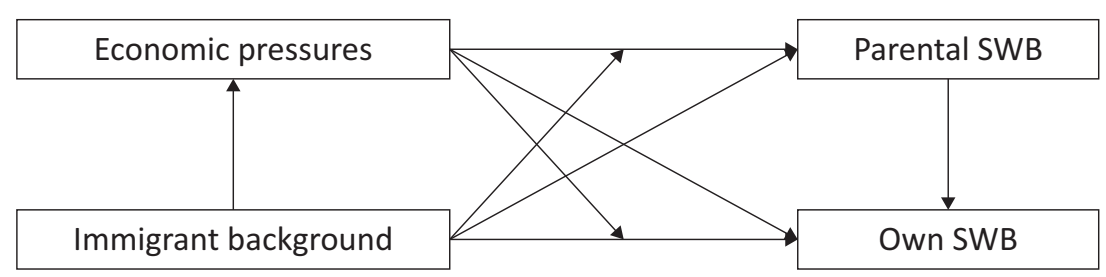

Figure 1. Hypothesized direct and indirect relationships between living in a family with an immigrant background and adolescents' and young adults' own subjective well-being (indicated as SWB). 
lonely (SFSO, 2019d). A community survey conducted in the canton of Zurich among adolescents however found that immigrants reported being depressed and anxious to a greater extent than both natives and dual citizens (no difference between the two groups; Steinhausen, Bearth-Carrari, \& Metzke, 2009). Studies based on nationally representative data have yet to be conducted to investigate the factors underlying the subjective wellbeing of adolescents and young adults with and without an immigrant background.

\section{Method}

\subsection{Data}

Analyses were carried out on the most recent available wave of the Swiss household Panel (Wave 17, from fieldwork done between September 2017 and March 2018). Data of the standard sample were complemented with an additional sample for the canton of Vaud (13.22\% of the final sample), which overrepresented low-income households. This is all the more important since immigrants, and in particular those in precarious economic conditions, usually tend to be underrepresented in Swiss large-scale surveys (Laganà, Elcheroth, Penic, Kleiner, \& Fasel, 2013). Using data from a household panel gives a unique insight on intra-family dynamics, since both parents and children were invited to report their subjective well-being.

\subsection{Sample}

We selected data from young people aged from 15 to 30 ( $M=19.97, S D=3.67)$, who lived with at least one of their parents and who filled the individual questionnaire ( $N=1$ '354; $51.40 \%$ female). About two thirds of the sample (66.99\%) had only Swiss citizenship, $26.81 \%$ were dual citizens and $6.20 \%$ were foreigners (subsamples' descriptive statistics are provided in Table 1$)$. The most represented countries of origin were Italy $(N=112)$, France $(N=80)$, Germany ( $N=39)$, former Yugoslavian countries and Albania (together, $\mathrm{N}=33$ ) and Portugal $(\mathrm{N}=25)$. The great majority of respondents was born in Switzerland (93.94\%) and had as first language the dominant language in the linguistic region of residence (94.39\%). Three quarters of the sample (76.41\%) reported being students.

Around three quarters of the respondents lived with both their parents (76.22\%), while $19.05 \%$ lived with their mother only and $4.73 \%$ lived with their father only. Altogether, data were available for 897 mothers (67.89\% Swiss, $20.51 \%$ dual citizens, and $11.59 \%$ foreigners) and 774 fathers ( $70.80 \%$ Swiss, $16.02 \%$ dual citizens, and $13.18 \%$ foreigners). Most mothers reported working part-time $(64.96 \%)$, while $12.83 \%$ worked full time and $22.21 \%$ reported another occupation. Differences were found according to mothers' origins. Immigrant mothers (19.23\%) or with dual citizenship (19.13\%) were more likely to work full time than native mothers $(9.85 \%)$, while a greater percentage of the latter worked part time (69.95\%; immigrants: $44.23 \%$, dual citizens: $60.11 \%$ ). By way of contrast, most fathers reported working fulltime $(73.95 \%)$. This rate was higher for natives $(80.29 \%)$ and dual citizens (84.68\%) than for immigrant fathers (69.91\%). 44.15\% mothers and 57.75\% fathers had a high school or higher diploma respectively. Again, this share varied across groups. Both mothers (58.15\%) and fathers (64.52\%) with dual citizenship had at least a high school diploma than natives (mothers: $40.89 \%$, fathers: $59.49 \%$ ) and immigrants (mothers: $38.46 \%$, fathers: $40.20 \%$ ). Finally, a minority of households (11.51\%) were below the poverty line (i.e., their disposable income was below $60 \%$ of the median value; note that missing income values were imputed). Economic pressures (measured with low satisfaction with household income; from $0=$ completely satisfied to $10=$ not at all satisfied) were on average low $(\mathrm{M}=2.84, \mathrm{SD}=2.24)$.

\subsection{Scores of Subjective Well-Being}

Respondents' subjective well-being was measured with two items:

1. How frequently do you experience the following emotions, if 0 means "never" and 10 "always"? (1) sadness and (2) anxiety;

Table 1. Descriptive statistics for the three subsamples (means and standard deviations are provided for continuous variables).

\begin{tabular}{lccc}
\hline & Natives & First-generation & Second-generation \\
\hline Age & $19.99(3.67)$ & $19.85(3.58)$ & $20.27(4.08)$ \\
\% female & $50.06 \%$ & $54.27 \%$ & $53.57 \%$ \\
\% born in Switzerland & $98.79 \%$ & $89.53 \%$ & $60.71 \%$ \\
\% dominant local language & $97.46 \%$ & $92.01 \%$ & $71.43 \%$ \\
\% in education & $75.39 \%$ & $80.11 \%$ & $71.43 \%$ \\
\% below poverty line & $11.14 \%$ & $9.64 \%$ & $33.33 \%$ \\
\% live with both parents & $78.50 \%$ & $68.87 \%$ & $83.33 \%$ \\
Negative affect (SWB) & $2.71(1.53)$ & $3.36(1.68)$ & $3.47(2.01)$ \\
\hline
\end{tabular}

Note: SWB stands for subjective well-being. 
2. Do you often have negative feelings such as having the blues, being desperate, suffering from anxiety or depression, if 0 means "never" and 10 "always"? $(\alpha=.74 ; \mathrm{M}=2.93, \mathrm{SD}=1.64)$.

The same items were used to estimate mothers' ( $\alpha=.78$; $\mathrm{M}=3.21, \mathrm{SD}=1.80)$ and fathers' $(\alpha=.77 ; \mathrm{M}=2.63$, $\mathrm{SD}=1.65)$ subjective well-being.

\subsection{Analytical Strategy}

Multilevel path models accounting for adolescents and young adults being nested within households were performed with Mplus 8.3. Indeed, a significant portion of the variance of respondents' subjective well-being (31.9\%; $\left.\sigma_{\text {household }}^{2}=0.86, \mathrm{SE}=0.15, p<.001\right)$ was due to the household structure of the data, which calls for multilevel analyses. Because around a quarter of the respondents lived with one parent only, separate models were performed for mothers and fathers. Respondents' citizenship status (Swiss vs. dual citizen; Swiss vs. foreigner) was used as proxy for "household with an immigrant background." However, a share of respondents did not report the same citizenship status (e.g., they are dual citizens and their parent is a foreigner) as their mother (18.61\%) or father (30.58\%). To ensure that mixed households did not stand out, whether young people shared or not a citizenship status with their parent was entered as a control variable in the model (along with its interaction with respondents' citizenship status). Also note that, while previous research on immigrants' well-being has typically compared individuals having migrated to the receiving country (first generation) to those born there (second generation; e.g., Arpino \& de Valk, 2018; Levecque \& van Rossem, 2015; Missinne \& Bracke, 2012), the very low proportion of respondents born abroad did not allow to use such a distinction in the current study. However, in a country where naturalization is a long and complicated process, dual citizenship can be considered an indicator of stronger ties with the host country.

Based on the FSM, low satisfaction with the household income was used as a measure of economic pressures and set as a predictor of parental well-being. Being below the poverty line, a measure of economic hardships, was treated as a control variable. Other control variables included: respondents' age, gender ( $1=\mathrm{fe}-$ male), and occupation ( 1 = in education); parental occupation (mother: working full-time vs. part-time and working full-time vs. other; father: working full-time vs. other), educational attainment (both parents: $1=$ high school diploma or higher), and presence of the other parent in the household. Both indirect and direct paths from nationality status to young people's subjective well-being were estimated (see Figure 1).

\section{Results}

Results are presented in Table 2 (mothers) and Table 3 (fathers). Preliminary (and unpresented) analyses showed that interactions between respondents' and parents' citizenship status, or citizenship status and economic pressures, had no significant impact. For this reason, these interaction terms were not included in the final models. Both final models were found to fit the data adequately (mothers: $\chi_{2}(6)=14.86, p=.02, \mathrm{CFI}=.977$, RMSEA $=.03$; fathers. $\chi_{2}(6)=8.09, p=.23, \mathrm{CFI}=.993$, RMSEA $=.02$; Hu \& Bentler, 1999). Most results are similar when considering maternal and paternal variables.

In line with previous research, young immigrants reported lower well-being than Swiss natives of the same age group (see first section, or the first column of both Table 2 and Table 3). The native-immigrant gap emerged

Table 2. Results of path model (respondents and their mothers).

\begin{tabular}{|c|c|c|c|c|c|c|}
\hline & \multicolumn{2}{|c|}{ SWB } & \multicolumn{2}{|c|}{ Parental SWB } & \multicolumn{2}{|c|}{ Economic pressures } \\
\hline & b & SE & b & SE & b & SE \\
\hline \multicolumn{7}{|l|}{ Swiss vs. } \\
\hline Foreigners & $0.45 * * *$ & 0.12 & $0.44 * *$ & 0.16 & $0.77^{* * *}$ & 0.18 \\
\hline Dual citizens & $0.54^{*}$ & 0.24 & 0.28 & 0.27 & $1.04 * *$ & 0.31 \\
\hline Same citizenship as parent & -0.09 & 0.14 & -0.17 & 0.21 & -0.30 & 0.22 \\
\hline Age & $0.03^{*}$ & 0.01 & & & & \\
\hline Female & $0.86 * * *$ & 0.09 & & & & \\
\hline In education & $0.31 * *$ & 0.12 & & & & \\
\hline Economic pressures & $0.06 *$ & 0.02 & $0.21 * * *$ & 0.04 & & \\
\hline Below poverty & 0.12 & 0.17 & 0.25 & 0.26 & $1.65 * * *$ & 0.31 \\
\hline Parental SWB & $0.16 * * *$ & 0.03 & & & & \\
\hline Other parent in $\mathrm{HH}$ & -0.13 & 0.13 & -0.08 & 0.17 & $-0.10 * * *$ & 0.19 \\
\hline \multicolumn{7}{|l|}{ Full time vs. } \\
\hline Part time & 0.10 & 0.16 & -0.18 & 0.21 & -0.05 & 0.21 \\
\hline Other occupation & 0.17 & 0.18 & -0.06 & 0.25 & $0.74 * *$ & 0.26 \\
\hline Parental education & 0.01 & 0.10 & -0.03 & 0.13 & $-0.49 * * *$ & 0.15 \\
\hline
\end{tabular}

Notes: ${ }^{* *} p<.001,{ }^{* *} p<.01,{ }^{*} p<.05 ;$ SWB stands for subjective well-being, HH for household. 
Table 3. Results of path model (respondents and their fathers).

\begin{tabular}{|c|c|c|c|c|c|c|}
\hline & \multicolumn{2}{|c|}{ SWB } & \multicolumn{2}{|c|}{ Parental SWB } & \multicolumn{2}{|c|}{ Economic pressures } \\
\hline & b & SE & b & SE & b & SE \\
\hline \multicolumn{7}{|l|}{ Swiss vs. } \\
\hline Foreigners & $0.37 * * *$ & 0.13 & $0.48 *$ & 0.20 & $0.68 * *$ & 0.24 \\
\hline Dual citizens & 0.29 & 0.24 & $1.04 * * *$ & 0.24 & $0.86^{*}$ & 0.35 \\
\hline Same citizenship as parent & -0.16 & 0.14 & -0.10 & 0.21 & -0.42 & 0.27 \\
\hline Age & $0.04 * *$ & 0.01 & & & & \\
\hline Female & $0.87 * * *$ & 0.09 & & & & \\
\hline In education & $0.33^{* *}$ & 0.12 & & & & \\
\hline Economic pressures & 0.07 & 0.03 & $0.16 * * *$ & 0.04 & & \\
\hline Below poverty & 0.08 & 0.18 & 0.31 & 0.27 & $1.82^{* * *}$ & 0.36 \\
\hline Parental SWB & $0.19 * * *$ & 0.04 & & & & \\
\hline Other parent in $\mathrm{HH}$ & -0.27 & 0.23 & 0.09 & 0.27 & -0.28 & 0.36 \\
\hline Full time vs. other & -0.08 & 0.12 & 0.07 & 0.17 & -0.09 & 0.18 \\
\hline Parental education & 0.02 & 0.10 & -0.17 & 0.14 & $-0.67 * * *$ & 0.17 \\
\hline
\end{tabular}

Notes: ${ }^{* *} p<.001,{ }^{* *} p<.01, * p<.05$; SWB stands for subjective well-being, $\mathrm{HH}$ for household.

even when parental well-being, economic pressures and control variables were considered, which suggests that intrafamily dynamics and economics did not fully explain the lower well-being expressed by immigrants. The difference between Swiss natives and dual citizens was significant only in the model including variables from the mothers' side. In both cases however, females, older respondents and those still in education reported a lower wellbeing. In addition, despite not directly hypothesizing the interaction between gender and origins, additional analyses revealed that the gender gap in subjective wellbeing was wider among dual citizens and immigrants (although present in all groups), but this only in the model including mothers (results available upon request).

Turning to parental well-being (see second column of both Table 1 and Table 2), parents of young immigrants were found to report more negative affect than parents of young natives. As explained above, this result emerged no matter whether the parents shared their children's citizenship status or not. The difference between dual citizens and Swiss natives was significant only when fathers were considered. No other variable (with the exception of economic pressures) had any significant effect on parental well-being. Importantly and as hypothesized in the present study, the lower the parental well-being (mothers and fathers alike), the lower children's well-being (see Tables 2 and 3, third section of first column).

The role of economic pressures is now examined. Economic pressures were higher in households below the poverty line, when the father was not present, when the mother did not work ('other occupation' category), and when mothers and fathers had no high school diploma. Compared to native families, households in which young people with an immigrant background lived (both immigrants and dual citizens) were characterized by higher economic pressures. In line with findings from the FSM, economic pressures impacted the well-being of both parents and their children.

Finally, indirect paths of the model (see Figure 1) from respondents' citizenship status to their reported well-being were examined. Considering either parents' well-being, the full FSM (i.e., immigrant background $\rightarrow$ economic pressures $\rightarrow$ parental well-being $\rightarrow$ young people's well-being) was found to be significant (immigrants vs. Swiss natives: $b_{\text {mothers }}=0.03, \mathrm{SE}=0.01$, $p=.003 ; b_{\text {fathers }}=0.02, \mathrm{SE}=0.01, p=.03$; dual citizens vs. Swiss natives: $b_{\text {mothers }}=0.04, \mathrm{SE}=0.01, p=.009$; $b_{\text {fathers }}=0.03, \mathrm{SE}=0.01, p=.05$ ). It is thus (at least partially) through economic pressures and low parental wellbeing that young people with an immigrant background experienced more negative affect than native youth. However, economic pressures also impacted directly (i.e., not through a low parental well-being) the well-being of young people with an immigrant background more than natives (immigrants vs. Swiss natives: $b_{\text {mothers }}=0.05$, $\mathrm{SE}=0.02, p=.02 ; b_{\text {fathers }}=0.05, \mathrm{SE}=0.03, p=.06$; dual citizens vs. Swiss natives: $b_{\text {mothers }}=0.06, \mathrm{SE}=0.03$, $p=.04 ; b_{\text {fathers }}=0.06$, SE $=0.03, p=.06$; note that the effects were only marginally significant in the model including paternal variables, which had a slightly lower sample size). Finally, the gap between young immigrants and Swiss natives was also directly (i.e., not through economic pressures) explained by a low parental wellbeing $\left(b_{\text {mothers }}=0.07, \mathrm{SE}=0.03, p=.02 ; b_{\text {fathers }}=0.09\right.$, $\mathrm{SE}=0.04, p=.03$ ), while the gap between dual citizens and Swiss natives was significant in the case of the fathers only $\left(b_{\text {mothers }}=0.05, \mathrm{SE}=0.05, p=.30\right.$; $b_{\text {fathers }}=0.19, \mathrm{SE}=0.06, p=.002$ ).

\section{Conclusion}

Taking advantage of a panel survey that contained selfreported measures of well-being for two generations, 
the present study examined the extent to which immigrant background and economic pressures affected the well-being of adolescents and young adults in Switzerland through the negative affects experienced by their parents. Confirming previous research on the topic (e.g., Levecque \& van Rossem, 2015; Missinne \& Bracke, 2012), in the Swiss context too adolescents and young adults with an immigrant background-both foreigners and dual citizens - reported being more anxious, sad and depressed than natives. Path models showed that young people with foreign roots were more likely to live in a household that experienced economic pressures, which, in a turn, impacted their parents' (mothers and fathers alike) well-being and their own. Having an immigrant background, experiencing economic pressures, and parents' well-being were also found to independently affect young people's negative affects.

\subsection{The Two Routes to Immigrants' Lower Well-Being}

Adolescents and young people who have an immigrant background suffer from a double burden: On the one hand, as individuals with foreign roots, they are likely to have first-hand experiences of discrimination (that impact individuals' well-being to a greater extent that simply knowing that one's group is discriminated against; see Schmitt, Branscombe, Postmes, \& Garcia, 2014); on the other hand, very likely their own parents have also personally suffered from discrimination. While unfortunately the survey used did not contain measures of perceived discrimination, the results of the present study suggest this double disadvantage. First, even when economic variables, parental well-being, and other factors known to impact individuals' well-being were taken into account, a gap in anxiety, sadness and depression between immigrant and native young people remained. This hints to possible personal experiences of discrimination and issues with integration. The fact that we did not find a significant interaction with the parents' citizenship status further suggests that young people's own citizenship status explains part of their well-being (for instance, natives with an immigrant or dual citizen parent did not appear to differ in well-being from a native with native parents). This pattern appeared in a survey where most respondents with an immigrant background came from countries neighboring Switzerland: They, or their (grand)parents, most likely immigrated voluntarily (unlike refugees for instance). We can thus assume that the gap should be even greater if immigrant groups that usually face stronger discrimination (such as those from more geographically distant and culturally different countries, e.g., Rapp, 2015; Stolz, 2005) were surveyed.

Findings regarding parents' well-being also support the assumption that the worse psychological health often reported by immigrants and dual citizens is not entirely due to poorer economic circumstances (e.g., on the role played by discrimination see Schunck et al., 2015), even though a lower satisfaction with the household fi- nancial situation (and other vulnerability related factors on the mother's side) did predict a lower parental wellbeing. Still our results indicate that economic conditions are an integral part of the story, and that any study on the native-immigrant gap should include measures of economic hardships and pressures. While second generation immigrants are less likely to be poor than natives (SFSO, 2019f), a low satisfaction with the household income was found in the present study to partly explain, beyond being above vs. below the poverty line, why young people with an immigrant background (the great majority of them being born in Switzerland) report a lower wellbeing than natives. Both immigrants and dual citizens appeared to be affected. Within families with foreign roots, economic pressures had a double impact: directly on the well-being of the young people, but also through their parents. This result highlights the role played by economic pressures (day-to-day hassles), which, according to the FSM, have to be distinguished from economic hardships (i.e., being poor). All in all, these findings highlight the complexity of the factors underlying the wellknown immigrant-native gap in well-being and psychological health.

\subsection{Maternal and Paternal Influences}

Maternal psychological health issues are generally found to have a slightly greater impact on young children's internalizing symptoms (e.g., anxiety, depression), which is explained by mothers spending on average more time with babies and toddlers (for a meta-analysis see Connell \& Goodman, 2002). This should be even more marked in countries such as Switzerland where there is no paternity leave, and where most women switch to part-time work after the birth of the first child (le Goff \& Levy, 2016). The results of the present study, however, showed that maternal and paternal (low levels of) well-being had an equally strong impact on adolescents and young adults (independently of their origins). The next step in future research should be to investigate how the well-being of parents of young people with an immigrant background interact, since research on within-family transmission of psychological health issues have shown that having both parents with poor mental health is an aggravating factor (e.g., Kahn, Brandt, \& Whitaker, 2004; Meadows, McLanahan, \& Brooks-Gunn, 2007).

Differences between mothers and fathers did emerge in the factors underlying economic pressures, though. While in both cases lower educational achievements were related to a lower satisfaction with household income, other factors appeared to make mothers more vulnerable: not being in employment (which was the case for hardly any father) and when the father did not live in the household. In Switzerland there are few work-family reconciliation policies and mothers generally work part time, which makes lone mothers with no or low employment particularly vulnerable. Also using data from the Swiss Household data, Struffolino, Bernardi, 
and Voorpostel (2016) showed that lone mothers suffer from poorer health than partnered mothers, a tendency which is aggravated in the case of low employment. Altogether, this suggests that lone mothers with an immigrant background cumulate disadvantages that are likely to affect the well-being of their children.

Confirming previous research conducted in Europe, the present study showed that adolescents and young adults with an immigrant background report lower wellbeing than native young people of the same age. A lower well-being at early stages of life can have life-long consequences, for example through lower educational achievement. Low well-being in middle school has for instance been related to lower attendance and low grades over time (Suldo, Thalji, \& Ferron, 2011). Policies that prevent children with an immigrant background from cumulating spiraling disadvantages from early in life should thus be implemented.

\section{Acknowledgments}

A part of this work was supported by the Swiss National Science Foundation (NCCR-On the Move Grant No. 51NF40-142020).

\section{Conflict of Interests}

The authors declare no conflict of interests.

\section{References}

Aisenberg, E., Trickett, P. K., Mennen, F. E., Saltzman, W., \& Zayas, L. H. (2007). Maternal depression and adolescent behavior problems: An examination of mediation among immigrant Latino mothers and their adolescent children exposed to community violence. Journal of Interpersonal Violence, 22, 1227-1249. https://doi.org/10.1177/0886260507304292

Anderson, R. E., Hussain, S. B., Wilson, M. N., Shaw, D. S., Dishion, T. J., \& Williams, J. L. (2015). Pathways to pain: Racial discrimination and relations between parental functioning and child psychosocial wellbeing. The Journal of Black Psychology, 41, 491-512. https://doi.org/10.1177/0095798414548511

Arpino, B., \& de Valk, H. (2018). Comparing life satisfaction of immigrants and natives across Europe: The role of social contacts. Social Indicators Research, 137, 1163-1184. https://doi.org/10.1007/ s11205-017-1629-x

Bengi-Arslan, L., Verhulst, F., van der Ende, J., \& Erol, N. (1997). Understanding childhood (problem) behaviors from a cultural perspective: Comparison of problem behaviors and competencies in Turkish immigrant, Turkish and Dutch children. Social Psychiatry and Psychiatric Epidemiology, 32, 477-484. https:// doi.org/10.1007/BF00789143

Bolzman, C., \& Vagni, G. (2018). And we are still here: Life courses and life conditions of Italian, Spanish and Por- tuguese retirees in Switzerland. In I. Vlase \& B. Voicu (Eds.), Gender, family, and adaptation of migrants in Europe (pp. 75-97). Cham: Palgrave Macmillan.

Conger, R. D., \& Conger, K. J. (2002). Resilience in Midwestern families: Selected findings from the first decade of a prospective, longitudinal study. Journal of Marriage and Family, 64, 361-373. https://doi. org/10.1111/j.1741-3737.2002.00361.x

Conger, R. D., Conger, K. J., \& Martin, M. J. (2010). Socioeconomic status, family processes, and individual development. Journal of Marriage and Family, 72, 685-704. https://doi.org/10.1111/j.1741-3737. 2010.00725.x

Connell, A. M., \& Goodman, S. H. (2002). The association between psychopathology in fathers versus mothers and children's internalizing and externalizing behavior problems: A meta-analysis. Psychological Bulletin, 128, 746-773. https://doi.org/10.1037/00332909.128.5.746

de Vroome, T., \& Hooghe, M. J. (2014). Life satisfaction among ethnic minorities in the Netherlands: Immigration experience or adverse living conditions? Happiness Studies, 15, 1389-1406. https://doi.org/ 10.1007/s10902-013-9483-2

de Vroome, T., \& Hooghe, M. J. (2015). Explaining the ethnic minority disadvantage in subjective well-Being: $A$ multilevel analysis of European countries. In F. Maggino (Ed.), A new research agenda for improvements in quality of life (Vol. 57, pp. 87-108). Cham: Springer.

Diener, E., Suh, E. M., Lucas, R. E., \& Smith, H. L. (1999). Subjective well-being: Three decades of progress. Psychological Bulletin, 125, 276-302. https://doi. org/10.1037/0033-2909.125.2.276

Ford, R. (2011). Acceptable and unacceptable immigrants: How opposition to immigration in Britain is affected by migrants' region of origin. Journal of Ethnic and Migration Studies, 37, 1017-1037. https:// doi.org/10.1080/1369183X.2011.572423

Giugni, M., \& Passy, F. (2004). Migrant mobilization between political institutions and citizenship regimes: A comparison of France and Switzerland. European Journal of Political Research, 43, 51-82. https://doi. org/10.1111/j.1475-6765.2004.00145.x

Havekes, E., Uunk, W., \& Gijsberts, M. (2011). Explaining ethnic outgroup feelings from a multigroup perspective: Similarity or contact opportunity? Social Science Research, 40, 1564-1578. https://doi.org/10.1016/ j.ssresearch.2011.06.005

Heizmann, B., \& Böhnke, P. (2019). Immigrant life satisfaction in Europe: The role of social and symbolic boundaries. Journal of Ethnic and Migration Studies, 45, 1027-1050. https://doi.org/10.1080/1369183X. 2018.1438252

Helbling, M. (2010). Naturalization politics in Switzerland: Explaining rejection rates at the local level. In T. Caponio \& M. Borkert (Eds.), The local dimension of migration policymaking (pp. 33-45). Amsterdam: Amsterdam University Press. 
Hou, Y., Kim, S. Y., Hazen, N., \& Benner, A. D. (2017). Parents' perceived discrimination and adolescent adjustment in Chinese American families: Mediating family processes. Child Development, 88, 317-331. https:// doi.org/10.1111/cdev.12603

Hu, L. t., \& Bentler, P. M. (1999). Cutoff criteria for fit indexes in covariance structure analysis: Conventional criteria versus new alternatives. Structural Equation Modeling: A Multidisciplinary Journal, 6, 1-55. https://doi.org/10.1080/10705519909540118

Kahn, R. S., Brandt, D., \& Whitaker, R. C. (2004). Combined effect of mothers' and fathers' mental health symptoms on children's behavioral and emotional well-being. Archives of Pediatric Adolescent Medicine, 158, 721-729. https://doi.org/10.1001/ archpedi.158.8.721

Kavanaugh, S. A., Neppl, T. K., \& Melby, J. N. (2018). Economic pressure and depressive symptoms: Testing the family stress model from adolescence to adulthood. Journal of Family Psychology, 32, 957-965. https://doi.org/10.1037/fam0000462

Laganà, F., Elcheroth, G., Penic, S., Kleiner, B., \& Fasel, N. (2013). National minorities and their representation in social surveys: Which practices make a difference? Quality \& Quantity, 47, 1287-1314. https://doi.org/ 10.1007/s11135-011-9591-1

Landers-Potts, M. A., Wickrama, K., Simons, L. G., Cutrona, C., Gibbons, F. X., Simons, R. L., \& Conger, R. (2015). An extension and moderational analysis of the family stress model focusing on African American adolescents. Family Relations, 64, 233-248. https:// doi.org/10.1111/fare.12117

le Goff, J.-M., \& Levy, R. (2016). Devenir parents, devenir inégaux [Becoming parents, becoming unequal]. Zurich: Seismo.

Levecque, K., Lodewyckx, I., \& Bracke, P. (2009). Psychological distress, depression and generalised anxiety in Turkish and Moroccan immigrants in Belgium: A general population study. Social Psychiatry and Psychiatric Epidemiology, 44, 188-197. https://doi.org/ 10.1007/s00127-008-0431-0

Levecque, K., \& van Rossem, R. (2015). Depression in Europe: Does migrant integration have mental health payoffs? A cross-national comparison of 20 European countries. Ethnicity \& Health, 20, 49-65. https://doi. org/10.1080/13557858.2014.88336

Malmusi, D. (2015). Immigrants' health and health inequality by type of integration policies in European countries. European Journal of Public Health, 25, 293-299. https://doi.org/10.1093/eurpub/cku156

Masarik, A. S., \& Conger, R. D. (2017). Stress and child development: A review of the Family Stress Model. Current Opinion in Psychology, 13, 85-90. https:// doi.org/10.1016/j.copsyc.2016.05.008

Meadows, S. O., McLanahan, S. S., \& Brooks-Gunn, J. (2007). Parental depression and anxiety and early childhood behavior problems across family types. Journal of Marriage and Family, 69, 1162-1177. https://doi.org/10.1111/j.1741-3737.2007.00439.x

Mendoza, M. M., Dmitrieva, J., Perreira, K. M., HurwichReiss, E., \& Watamura, S. E. (2017). The effects of economic and sociocultural stressors on the well-being of children of Latino immigrants living in poverty. Cultural Diversity and Ethnic Minority Psychology, 23, 15-26. https://doi.org/10.1037/cdp0000111

Missinne, S., \& Bracke, P. (2012). Depressive symptoms among immigrants and ethnic minorities: A population based study in 23 European countries. Social Psychiatry and Psychiatric Epidemiology, 47, 97-109. https://doi.org/10.1007/s00127-010-0321-0

Nguyen, A.-M. D., \& Benet-Martínez, V. (2013). Biculturalism and adjustment: A meta-analysis. Journal of Cross-Cultural Psychology, 44, 122-159. https://doi. org/10.1177/0022022111435097

Oppedal, B., Røysamb, E., \& Sam, D. L. (2004). The effect of acculturation and social support on change in mental health among young immigrants. International Journal of Behavioral Development, 28, 481-494. https://doi.org/10.1080/01650250444000126

Özbek, E., Bongers, I. L., Lobbestael, J., \& van Nieuwenhuizen, C. (2015). Turkish and Moroccan young adults in the Netherlands: The relationship between acculturation and psychological problems. Journal of Immigrant and Minority Health, 17, 1687-1696. https://doi.org/10.1007/s10903-015-0203-3

Pilowsky, D. J., Wickramaratne, P., Poh, E., Hernandez, M., Batten, L. A., Flament, M. F., . . Weissman, M. M. (2014). Psychopathology and functioning among children of treated depressed fathers and mothers. Journal of Affective Disorders, 164, 107-111. https:// doi.org/10.1016/j.jad.2014.04.012

Ponnet, K. (2014). Financial stress, parent functioning and adolescent problem behavior: An actor-partner interdependence approach to family stress processes in low-, middle-, and high-income families. Journal of Youth and Adolescence, 43, 1752-1769. https:// doi.org/10.1007/s10964-014-0159-y

Potarca, G., \& Bernardi, L. (2018). The (un)healthy migrant effect: The role of legal status and naturalization timing. In R. Tillman, M. Voorpostel, \& P. Farago (Eds.), Social dynamics in Swiss society (pp. 79-93). Cham: Springer.

Rapp, C. (2015). More diversity, less tolerance? The effect of type of cultural diversity on the erosion of tolerance in Swiss municipalities. Ethnic and Racial Studies, 38, 1779-1797. https://doi.org/10. 1080/01419870.2015.1015582

Schmitt, M. T., Branscombe, N. R., Postmes, T., \& Garcia, A. (2014). The consequences of perceived discrimination for psychological well-being: A meta-analytic review. Psychological Bulletin, 14, 921-948. https:// doi.org/10.1037/a0035754

Schunck, R., Reiss, K., \& Razum, O. (2015). Pathways between perceived discrimination and health among immigrants: Evidence from a large national panel survey in Germany. Ethnicity \& Health, 20, 493-510. 
https://doi.org/10.1080/13557858.2014.932756

Swiss Federal Statistical Office. (2019a). Enquête sur le vivre ensemble en Suisse (VeS): Résultats 2018 [Survey on "living together" in Switzerland: 2018 results]. SFSO. Retrieved from https://www.bfs. admin.ch/bfs/fr/home/statistiques/population/ migration-integration/vivre-ensemble-suisse. assetdetail.7466705.html

Swiss Federal Statistical Office. (2019b). Population résidante permanente selon le sexe et la catégorie de nationalité, résultats annuels provisoires [Resident population according to sex and nationality category, provisory annual results]. SFSO. Retrieved from https://www.bfs.admin.ch/bfs/en/home/statistics/ population.assetdetail.7966020.html

Swiss Federal Statistical Office. (2019c). Santé autoévaluée [Self-reported health]. SFSO. Retrieved from https://www.bfs.admin.ch/bfs/fr/home/statistiques/ population/migration-integration/indicateursintegration/tous-indicateurs/sante/sante-autoevaluee.html

Swiss Federal Statistical Office. (2019d). Sentiment de solitude [Feelings of loneliness]. SFSO. Retrieved from https://www.bfs.admin.ch/bfs/fr/home/ statistiques/population/migration-integration/ indicateurs-integration/tous-indicateurs/sante/ sentiment-solitude.html

Swiss Federal Statistical Office. (2019e). Taux d'activité des 15-64 ans [Activity rate, 15-64 years old]. SFSO. Retrieved from https://www.bfs.admin.ch/ $\mathrm{bfs} / \mathrm{fr} /$ home/statistiques/population/migrationintegration/indicateurs-integration/tousindicateurs/marche-travail/taux-activite.html

Swiss Federal Statistical Office. (2019f). Taux de pauvreté [Poverty rate]. SFSO. Retrieved from https://www.bfs.admin.ch/bfs/fr/home/statistiques/ population/migration-integration/indicateursintegration/tous-indicateurs/aide-socialepauvrete/taux-pauvrete.html

Sobolewski, J. M., \& Amato, P. R. (2005). Economic hardship in the family of origin and children's psychological well-being in adulthood. Journal of Marriage and Family, 67, 141-156. https://doi.org/10.1111/j. 0022-2445.2005.00011.x

Steinhausen, H.-C., Bearth-Carrari, C., \& Metzke, C. W. (2009). Psychosocial adaptation of adolescent migrants in a Swiss community survey. Social Psychiatry and Psychiatric Epidemiology, 44, 308-316. https:// doi.org/10.1007/s00127-008-0437-7

Stevens, G. W., \& Vollebergh, W. A. (2008). Mental health in migrant children. Journal of Child Psychology and Psychiatry, 49, 276-294. https://doi.org/10.1111/j. 1469-7610.2007.01848.x

Stolz, J. (2005). Explaining Islamophobia. A test of four theories based on the case of a Swiss city. Swiss Journal of Sociology, 31, 547-566.

Struffolino, E., Bernardi, L., \& Voorpostel, M. (2016). Self-reported health among lone mothers in Switzerland: Do employment and education matter? Population, 71, 187-213. https://doi.org/10.3917/popu. 1602.0193

Suldo, S., Thalji, A., \& Ferron, J. (2011). Longitudinal academic outcomes predicted by early adolescents subjective well-being, psychopathology, and mental health status yielded from a dual factor model. The Journal of Positive Psychology, 6, 17-30. https://doi. org/10.1080/17439760.2010.536774

Walsh, S. D., Harel-Fisch, Y., \& Fogel-Grinvald, H. (2010). Parents, teachers and peer relations as predictors of risk behaviors and mental well-being among immigrant and Israeli born adolescents. Social Science \& Medicine, 70, 976-984. https://doi.org/10.1016/ j.socscimed.2009.12.010

White, R. M. B., Liu, Y., Nair, R. L., \& Tein, J.-Y. (2015). Longitudinal and integrative tests of family stress model effects on Mexican origin adolescents. Developmental Psychology, 51, 649-662. https://doi.org/ 10.1037/a0038993

Zhang, X. (2014). Family income, parental education and internalizing and externalizing psychopathology among 2-3-year-old Chinese children: The mediator effect of parent-child conflict. International Journal of Psychology, 49, 30-37. https://doi.org/10.1002/ ijop.12013

\section{About the Authors}

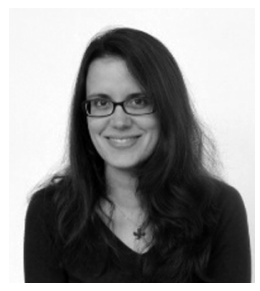

Oriane Sarrasin (PhD) is Lecturer in Social Psychology at the University of Lausanne, Switzerland. In her research she examines how both individual and contextual factors shape how people react toward social and political objects such as climate change, immigration and gender equality. She does so by relying on survey data combined with contextual information. She also uses experiments to evaluate social influence mechanisms in campaigns or political posters.

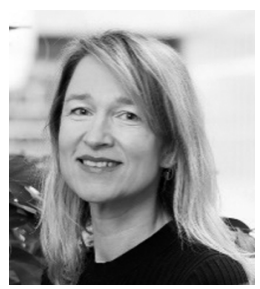

Eva G. T. Green (PhD) is Associate Professor in Social Psychology at University of Lausanne, Switzerland. At the crossroads of social, cross-cultural and political psychology, her research interests focus on intergroup relations (e.g., prejudice, power relations, political identities) in multicultural societies. Her research is mainly informed by survey, experimental and mixed methods approaches. She is currently leading a project within nccr-On the move (National Center of Competence in Research-The Migration-Mobility Nexus) funded by the Swiss National Science Foundation. 

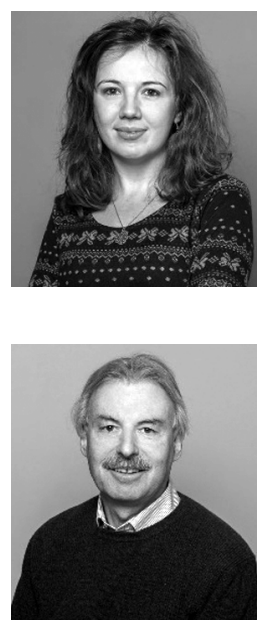

Claudio Bolzman (PhD) is Professor in Sociology at University of Applied Sciences and Arts Western Switzerland (HES-SO Geneva). His research interests focus on migrations, life course and intergenerational relations. He is currently member of the nccr LIVES (National Center of Competence in Research-Overcoming Vulnerability. Life Course Perspectives) funded by the Swiss National Science Foundation.

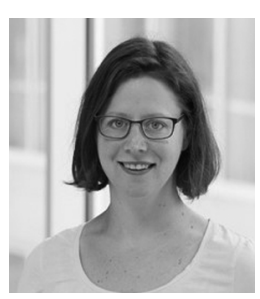

Ursina Kuhn (PhD) is Senior Researcher at the Swiss Centre of Expertise in the Social Sciences (FORS), where she works for the Swiss Household Panel (SHP). She holds a master and a PhD in Political Science from the University of Zurich. Current research interests comprise subjective well-being, quality of survey data, income and wealth distribution and consequences of negative life events on party preferences. 